\title{
COMPARATIVE ANALYSIS OF RUSSIAN AND ENGLISH LOANWORDS
}

\author{
Natallia Golyakevich \\ Senior Lecturer of the Department of Theoretical and Applied Linguistics \\ Mogilev State University by A. A. Kuleshov (Mogilev, the Republic of Belarus) \\ e-mail: goliakevich@msu.by \\ ORCID: 0000-0001-7373-5268
}

This article is devoted to the topic "Borrowings in Russian and English». This problem is relevant, since language borrowings extend their influence to a wide variety of areas of activity. No language is "pure». Every language has an admixture of borrowings. Russian and English are no exception.

In addition, borrowing words from other languages is one of the ways to develop a language. The language always responds flexibly and quickly to the needs of the public. Borrowings are the result of contacts and relationships between peoples and states.

In this article we made an effort to find out the reasons of borrowing the Russian words in English and English words in Russian, condition of their existence, consider a concept «Language borrowing», find out the sources of borrowing words, classify the often used borrowing according the spheres of communication.

Keywords: linguistic borrowing; language development; classification of the vocabulary; the periods of preferential loans; the classification of the Russian borrowings; the classification of the English borrowings.

\section{Голякевич Наталія. Порівняльний аналіз запозичень у російській та англійській мовах. \\ Статтю присвячено порівняльному аналізу запозичень у російській і англійській} мовах. Задекларована проблема є актуальною, оскільки мовні запозичення поширюють свій вплив на різні сфери діяльності. Жодна мова не є «чистою», у кожній мові $е$ значна частка запозичень. Російська та англійська мови не є винятком. Крім того, запозичення слів з інших мов - один зі способів розвитку мови. Мова завжди гнучко $i$ швидко реагує на потреби громадськості. Запозичення є результатом контактів $i$ відносин між народами, державами. У статті ми спробували з'ясувати причини запозичення російських слів в англійську мову і англійських слів у російську мову, умови їх функиіювання, проаналізували поняття «мовна запозичення», з'ясували джерела запозичення слів, класифікували часто вживані запозичення за сферами комунікації.

Ключові слова: мовні запозичення; розвиток мови; класифікація словникового складу; періоди запозичень; класифікачія російських запозичень; класифікація англійських запозичень.

Language borrowing is a process that results in the appearance and consolidation of a certain foreign language element in a language. Through borrowing, the vocabulary of the language is replenished; it reflects cultural, social and economic ties.

Borrowing in languages is one of the most important factors in their development. It is difficult to calculate the huge number of borrowings, as the process of penetration of foreign-language elements is constantly increasing. In each language, you can distinguish the following lexical layers ๑ Golyakevich N., 2020 that are typical of one language family: words that are typical 
of all languages of the same family; words that are common to a group/subgroup of related languages; native words of a particular language; borrowed words.

The classification of English vocabulary:

1) Indo-European words: mother, daughter, meat, hear, stand;

2) German words: say, see, white, winter;

3) West German words: age, ask, love, south;

4) Proper English words: boy, girl, lady, lord;

5) Borrowings: sputnik, taiga (from Russian); samurai, sumo (from Japanese).

This generally accepted classification cannot be called absolutely correct, since words that at first glance seem Indo-European may have been borrowed from other proto-languages, since various relations have existed between peoples since ancient times.

Words that were borrowed in ancient times were completely assimilated in the language and are no longer perceived as foreign. It is often difficult to determine the process of a word origin and the language which is the source of origin. The role of loanwords in different languages has had different effects on vocabulary enrichment. In some languages, its role was insignificant, and in other languages, borrowing during different historical epochs had such an impact on the vocabulary of the language that even auxiliary words (for Example: they, them - Scandinavian pronouns that replaced old English words with the same meanings), borrowed from other languages, replaced the original auxiliary words.

Modern English has come a long way. All the changes that the language has undergone are due to numerous reasons related to various conquests, wars, the development of trade, and many others. In order for the language to fully perform its main function (communication), the vocabulary must respond in a timely manner to changes in all areas of human life (production, science, world outlook, socioeconomic relations, everyday life) [Бородина 2015, p. 904]. The adoption of Christianity had a huge impact on the composition of the English language, which brought all of England into contact with Latin civilization. In modern language, such words as: ancor from ancora(якорь); purs from bursa (сумка); socc from soccus (тапки); pound/pound from pondo (фунть); camel from camelus(верблюд); rose from rosa (роза); Bishop (bishop) from episcopus (епискоn) still exist. Over the course of its existence, English has borrowed words from more than 50 languages, but the most important sources of borrowing are Latin, French, and Scandinavian.

As for the Russian language, the nature and volume of borrowings can determine the ways of historical development of the language. By crossing it with other languages, you can understand its history and dialects. When they enter the Russian language, borrowings adapt and undergo the necessary semantic and phonetic changes. In the history of the Russian language, the following periods of preferential borrowings should be distinguished:

1) pre-Slavic period (borrowings from Germanic languages and Latin);

2) the era of Christianization and book influence (borrowings from Greek and old / Church Slavonic);

3) XVI - XVIII centuries (borrowings from the Polish language);

4) XVIII - XIX centuries (borrowings from Dutch, German and French);

5) the beginning of the XX century - our days (borrowings from English).

Every day we are confronted with words of foreign origin: the summit, a flash $m o b$ etc. These words are so firmly established in the Russian language that we do not think about the fact that these words came to us from another language. 
Borrowings from English are called anglicisms. The dictionary of S. Ozhegov gives this definition to anglicism: "Anglicism is a word or turn of speech in a language borrowed from the English language or modeled on an English word or expression» [Ожегов, Шведова 1999, p. 47]. The most intensive penetration is observed in the 1990 s of the $20^{\text {th }}$ century, as well as after the collapse of the USSR due to the flourishing of foreign tourism and the activation of business and cultural ties. In the modern world, English is the most important means of international communication, so the Russian language has a huge number of anglicisms:

Food: джем, крамбл, крекер, панкейк, ростбиф, хот-дог, чипсы;

Clothing: айвори, бандана, боди, бутсы, виндпруф, джинсы, клатч;

Sports: армрестлинг, баскетбол, бодибилдинг, скуба-дайвинг, допинг;

IT technologies: блог, браузер, виральный, геймер, девайс, дисплей;

Economic sphere:аутсорсинг, бренд, брокер, дедлайн, дефолт.

Until the end of the $18^{\text {th }}$ century, the English language was actively supplemented by borrowings from other languages. The Russian language was not left out, as cultural ties between England and Russia have existed for a long time. The first Russian words that appeared in English were recorded in the $14^{\text {th }}$ century. The next wave took place in the $16^{\text {th }}$ century, after the establishment of more regular economic and political ties between these countries.

Society is a complex system of specially organized human activity. Like all other systems, the society is composed of subsystems. And the most important of these subsystems is the system of spheres of public life. The sphere of social life is a certain set of stable relations between social subjects.

The classification of Russian loanwords in English by spheres of public life can include:

certain types of people's activities (educational, political, religious, etc.);

social institutions (school, family, Church, parties, etc.); activity)

relationships between people (relationships that have arisen in the course of

There are usually 4 main spheres of social life: social (peoples, nations, classes), economic, political (state, parties,), spiritual (religion, science, art, education).

As for the social sphere, it includes various social communities and relationships between them.

Shuba, kvass, morse, koumiss, shchi, borshch, mead, calash, shashlik, kissel, vodka, nalivka, nastoika, blind, oladyi, okroshka, izba, telega, peach, bayan, samovar, tarantass, droshky, makhorka, step, tundra, taiga, polinia, suslik, borzoi, sagene, rouble.

1. Women aren't allowed to make shashlik.

Шашлык женских рук не терпит.

2. This shows the number of days that the tundra in Alaska is frozen enough to drive on it.

Это график количества дней, в которые тундра на Аляске замерзла достаточно для того, чтобы водить там машину.

3. I ask myself why he needed the samovar.

Я задаюсь вопросом, для чего ему нужен был самовар.

4. The most famous Ukrainian dish is, of course, borshch.

Самое известное украинское блюдо - это, конечно же, борщ.

5. Sour-sweet cranberries are traditional addictive to Slavic kvass. 
Кисло-сладкая клюква является традииионной добавкой, которая используется в славянских квасах.

6. Basic currency for prize payouts is the Russian rouble.

Базовой валютой для выплаты призов является российский рубль.

7. Koumiss production was paid particular attention in our republic within the last years.

Производству кумыса в последние годы в нашей республике уделяется особое внимание.

8. Never write the word «shchi» in German.

Никогда не пиши слово «щи» по-немецки.

9. This vodka got large popularity, due to its excellent quality.

Эта водка получила большую популярность за свое великолепное качество.

10. The Sisterhood invites everyone to bliny next Sunday, February $22^{\text {nd }}$, after Liturgy.

Сестричество приглашает всех на блины в следующее воскресенье, 22 февраля, после Литургии.

The political sphere is one of the most important spheres of public life. It expresses the relations of people connected primarily with the government, which ensure joint security.

Tzar, voivode, knes, bojar, moujik, Cossack, opritchina, strelscy, starosta, ukase, kremlin, sotnia, Raskolnik, ataman, Cadet, druzhina, duma, apparat, Bolshevik, commissar, glasnost, komsomol, Menshevik.

1. Maybe the Tzar wanted their land.

Может, царю понадобились их земли.

2. What's the statue of a Romanian voivode doing here?

Что здесь делает статуя румынского воеводы?

lie.

3. Now, this Cossack comes and destroys all my hard work by his outrageous

Теперь приезжает этот казак и рушит мой тяжельй труд своей возмутительной ложью. effective.

4. Kremlin support has made Serbia's nationalist intransigence over Kosovo

Поддержка Кремля способствовала националистической непримиримости Сербии в отношении Косово.

5. I thought you lost all your memory, cadet.

Я думал, ты потерял память, кадет.

6. We hope that the Russian Duma will soon do likewise.

Мы надеемся, что вскоре то же самое сделает и Российская Дума.

7. A Bolshevik anticommunism, similar in its dogmatism to communism itself, has from time to time run riot in parts of Eastern Europe.

Больмевистский антикоммунизм, своим догматизмом напоминающий коммунизм, время от времени выходил из под контроля в разных областях Восточной Европьл.

8. I went to the Komsomol committee and asked to be sent to the steppe.

Я пошла в комитет комсомола и попросила отправить меня на целину.

Of all the above mentioned, we would like to note that not all areas of public life in the UK have got borrowings from the Russian language. Mostly Russian borrowings can be found in the social and political spheres. Russian words that have penetrated into the English language, in their meaning, are various kinds of names of 
ruling officials and subordinates, institutions, names of household items and geographical names. Each bright event generated new words, sometimes they were broadcast and in this form passed into the English language.

Russian loanwords, in contrast to Russian loanwords in English, contain a huge number of words from the English language, since in the modern world, English is the most important means of international communication. The expansion of international contacts and the superiority of English-speaking countries in almost all spheres of activity contribute to the constant appearance of English loanwords in the Russian language. English loanwords in Russian are commonly called «anglicisms». Anglicism is a word or phrase in a language borrowed from the English language or modeled after an English word or expression.

Let's look at anglicisms in the life of the Russian-speaking people in details. According to the concentration of anglicisms, the social sphere can be divided into groups such as food, clothing, sports, etc.

Food: 1. джем, крамбл, крекер, панкейк, ростбиф, хот-дог, чипсы, иортбред, чизбургер, барбекю, поп-корн, фреш, йогурт, пудинг, ланч.

1. Ева заказала ростбиф, я курииу.

Eva had roast beef and I had chicken.

2. А едой будет гамбургер или хот-дог.

And then the food is either hamburger or hotdog.

3. Программа перевода допускает получасовой ланч, если ты закончил со своими обязанностями.

The diversion program allows for a half-hour lunch once you've completed your duties. маслом.

4. Крекер с добавлением лука, поверхность орошена растительным

Cracker with onion, the surface is sprinkled with vegetable oil.

5. Клэр устраивает в выходные большое барбекю.

Claire is doing a big barbecue at the weekend.

Clothing: айвори, бандана, боди, бутсы, виндпруф, джинсы, клатч, коттон, кэжуэл, кэтеринг, легzинсы, лонгслив, свитер, смокинг, стретч, топ, хилисы, худи, шопинг, шорты, шузы.

1. В США многие пожилье люди носят джинсы.

In the U.S. many old people wear jeans.

2. Она подарила мне свитер на день рождения.

I received a sweater from her on my birthday.

3. Вдоль дома шел парень, одетьй в худи.

A boy walked by the house wearing a hoodie.

4. Мне нравится топ, но шорты нужны подлиннее.

I liked the top but I need the shorts to be longer.

5. Оригинальный клатч от Шанель, который я взяла напрокат $и$ должна вернуть завтра к 5 вечера.

It's a Chanel original clutch on loan to me and due back tomorrow by 5 p.m.

Sports: армрестлинг, баскетбол, бодибилдинг, скуба-дайвинг, допинг, керлинг, кикбоксинг, кросс, пенальти, роуп-джампинг, серфинг, скейтборд, спорт, старт, тайм, фитнес, форвард.

1. Даже болельщики, которые были на стадионе, почти все посчитали, что пенальти был чистылм.

Even fans present at the stadium felt that the penalty was clean in their mass. 
2. Его хобби - бодибилдинг, поэтому у него твердое плотное тело с ярко выраженными мышщцами.

Bodybuilding is his hobby so he has a very firm tight body with lots of muscle definition.

It is necessary to highlight separately the sphere of IT technologies or information and communication technologies. Currently, technologies are developing at a large-scale pace. It is almost impossible to imagine a person's daily life without this sphere. That is why the sphere of information and communication technologies occupies an important place in people's lives. In the IT field, almost all words are taken from the English language. Let's try to give the most frequently used words.

Блог, браузер, виральный, геймер, девайс, дисплей, драйвер, Интернет, кликать, компьютер, комьюнити, логин, монитор, ноутбук, пост, принтер, провайдер, процессор, сайт, сканер, смайлик, трафик, хакер, юзер.

1. После загрузки пользователю предоставляется обычный логин.

After booting they just present a regular login.

2. В холле имеется ноутбук с бесплатным доступом в Интернет.

In the lobby there is a notebook with free internet access available.

3. Наш новый сканер отправился в ад.

Now our old scanner is shot to hell.

4. При успешной установке соединения, браузер перенаправляется на запрашиваемый веб-сайт. Website.

Upon a successful connection, the browser is redirected to the specified

5. Информащия о состоянии счета поступит на дисплей вашего телефона. display.

Information about your account status will be indicated on your phone's

The economic sphere is a set of people's relations that arise when creating and transferring material goods. English is often used in high-level negotiations. All the terms from the world of economics are based on the words of English origin.

Аутсорсин, брено, брокер, дедлайн, дефолт, диверсификация, дилер, дистрибьютор, инвестор, краудфандинг, лизинг, маркетинг, менеджсмент, нетворкинг, ноу-хау, пиар, прайм-тайм, прайс-лист, промоутер, релиз, ритейлер, риэлтор, стартап, фрилансер, холдинг.

1. Прибыли распределяются по заранее согласованной формуле, а убытки несет исключительно инвестор.

Profits are distributed on the basis of a pre-agreed formula, while losses are borne exclusively by the investor.

2. Это единственный дедлайн, который я хочу пропустить.

This is one deadline I want to miss.

3. Этот стартап начал радикально разрушать изнутри подход правительства к ведению бизнеса.

This start-up_is fundamentally beginning to disrupt the way government does business from the inside out.

4. Иногда плата за лизинг может превышать стоимость банковских кредитов.

Sometimes lease payments can be more expensive than bank charges.

From all the mentioned above, we can conclude that there is a fairly large influx of anglicisms into the Russian language. Due to the progress in computer, technical, financial and economic spheres, a large number of words from English 
began to enter the Russian language. The vocabulary of Russian people does not contain equivalents for such realities as, for example, a laptop, a scanner, a blog, impeachment, etc. It is generally believed that anglicisms penetrate into the Russian language through slang. It pushed the normative vocabulary. People are used to and sometimes do not even realize that certain words are loanwords, and not native Russian words at all.

Borrowing foreign words is one of the ways to develop a language. A language has always responded deftly to the needs of the public. Borrowing is the result of contact and interaction between peoples, societies and states. The main ways to borrow vocabulary include transcription, transliteration, calculus, and semantic borrowing.

In Russian, there is a fairly large influx of anglicisms. This is due to the progress in the computer, technical, financial and economic spheres. The vocabulary of Russian people does not contain equivalents for such realities as, for example, a laptop, a scanner, a blog, impeachment, etc. It is generally believed that anglicisms penetrate the Russian language through slang. He pushed the normative vocabulary. People are used to and sometimes do not even realize that certain words are loanwords, and not native Russian words at all.

There are many more borrowings in Russian than in English. The English language has spread to all continents of the globe. This is why English is considered an international language.

\section{LITERATURE}

Thomason, Sarah G. (2001). Language Contact : An Introduction. Washington, 310 p.

Баш, Л. М. (1989). Дифференциачия термина «заимствование»: хронологический и этимологический аспекты. Москва, 300 с.

Бородина, М. А. (2015). Латинский язык в современном мире. [In:] Молодой ученый, вып. 12, с. 898-906.

Казакова, Т. А. (2001). Практические основы перевода. Санкт-Петербург, 269 с.

Крысин, Л. П. (1996). Иноязычные слова в современной жизни. Английский язык кония ХХ столетия. Москва, с. 63-65.

Латышев, Л. К. (2001). Технология перевода. Москва, 280 с.

Нелюбин, Л. Л. (2006). Толковый переводоведческий словарь. Москва, 320 с.

Ожегов, С. И. и Шведова, Н. Ю. (1999). Толковый словарь русского языка: 80000 слов и фразеологических выражений. 4-е изд. Москва, 940 с. 